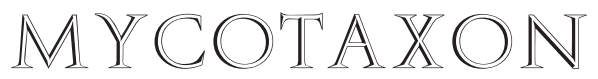

Volume 111, pp. 309-322

January-March 2010

\title{
New and rare coelomycetes with appendage-bearing conidia from Pondoland, South Africa
}

\author{
Seonju Marincowitz ${ }^{1}$, Marieka Gryzenhout ${ }^{2}$ \\ \& Michael J. WingField \\ ${ }^{1}$ seonju.marincowitz@fabi.up.ac.za ${ }^{2}$ marieka.gryzenhout@fabi.up.ac.za \\ Forestry and Agricultural Biotechnology Institute (FABI) \\ Tree-Protection Co-operative Programme (TPCP) \\ DST/NRF Centre of Excellence in Tree Health Biotechnology (CTHB) \\ University of Pretoria, Pretoria 0001, Republic of South Africa
}

\begin{abstract}
During a mycological excursion to the Pondoland region of South Africa in 2008, six interesting anamorphic fungi with appendage-bearing conidia were isolated. They are Bartalinia pondoensis, Crucellisporium umtamvunae, and Mycohypallage margaretae, all of which are new to science, Mycohypallage congesta with a new observation of gelatinous basal appendage, Mycotribulus mirabilis on a new host plant, Apodytes, and Chaetospermum camelliae. Morphological characters are described and notes provided. The teleomorphic affinity of C. umtamvunae to the Helotiales is proposed based on DNA sequence data.
\end{abstract}

Key words - Maputaland-Pondoland-Albany (MPA), biodiversity hotspot, microfungi

\section{Introduction}

South Africa has a rich biological diversity, harbouring four of 34 biodiversity hotspots in the world (http://www.biodiversityhotspots.org). Among them is the Maputaland-Pondoland-Albany (MPA) center, which lies on the east coast of southern Africa, which shelters about 600 tree species, representing the highest tree richness of any known temperate forest and comprising $80 \%$ of South Africa's remaining forests (Silander 2001). As indicated by its name, the MPA consists of three areas - Maputaland (M) from southern Mozambique, Pondoland (P) in the middle, and Albany further south in South Africa's Eastern Cape Province (FIG. 1). The Pondoland forms the focus of this study and is home to approximately 1800 vascular plants, including more than 120 endemic species (Steenkamp et al. 2004). The Umtamvuna Nature Reserve (UNR), located near Port Edward in KwaZulu-Natal, South Africa, is a major conservation area of the Pondoland. 


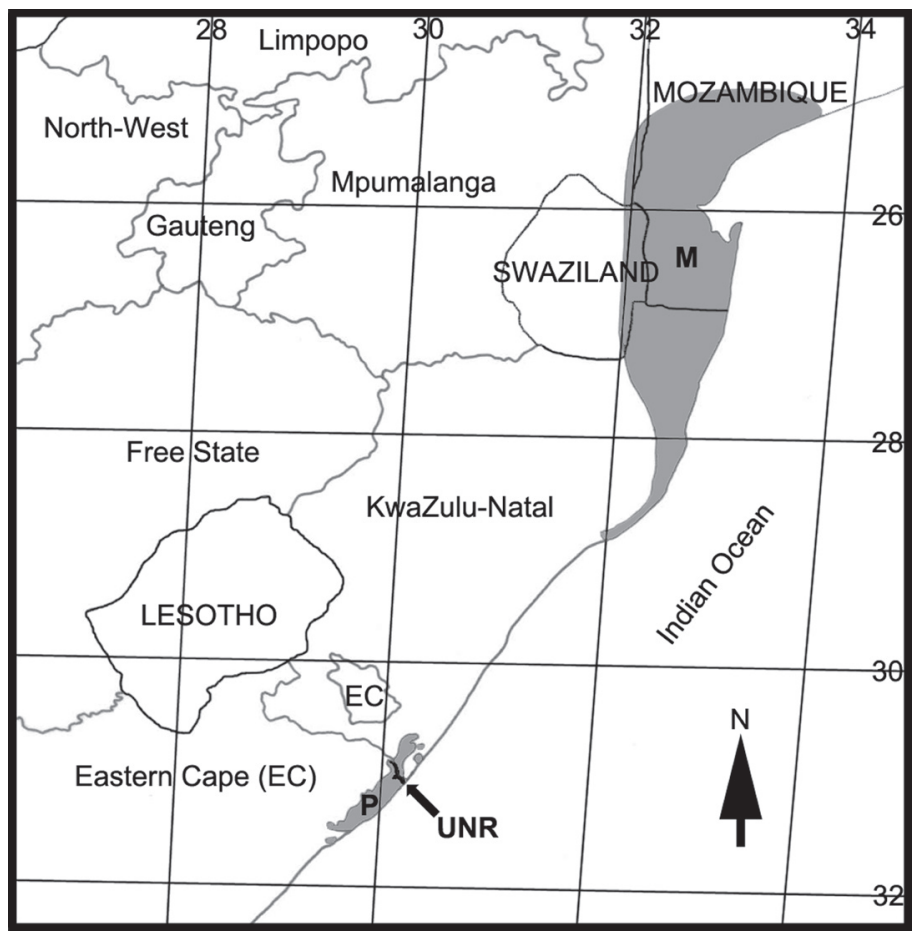

FIg.1. The location of the Maputaland-Pondoland-Albany center of biodiversity hotspot and the collection site. $\mathrm{M}-$ Maputaland region, $\mathrm{P}-$ Pondoland region, UNR-the Umtamvuna Nature Reserve.

The UNR is acknowledged for its floral richness and high level of endemism (Abbott \& Van Wyk 2000). However, the UNR mycobiota has not drawn much attention: only 51 macrofungi and lichens were listed by Abbott \& Van Wyk (2000). There have also been no surveys of the fungal diseases of plants, some of which could be caused by alien invasive pathogens.

This project was initiated to study plant pathogenic fungi in the UNR. During this pilot investigation several rare and new micro-fungi were encountered. These included six coelomycete fungi with conidial appendages that were associated with minor leaf spots or were dormant inside the healthy tissues. They are presented in this paper with full descriptions.

\section{Materials and methods}

The Umtamvuna Nature Reserve and "Red Desert" at Port Edward were visited in May 2008. In the UNR, two hiking-trails (i.e., Porcupine and Fish Eagle), were chosen based 
on tree distribution and accessibility. Living leaves showing disease symptoms such as leaf spots or leaf necrosis and healthy asymptomatic leaves were collected.

Leaf spots with visible fungal structures were directly re-hydrated with a drop of sterile water. Asymptomatic specimens were re-hydrated in moisture chambers to induce the growth of fungi inside of the tissue. Fungi were isolated by removing fungal structures or oozing spores with a needle. Single spore isolation was established on $2 \%$ malt extract agar (MEA), supplemented with streptomycin. Reference cultures were deposited in the culture collection (CMW) of the Forestry and Agricultural Biotechnology Institute at the University of Pretoria, Pretoria, South Africa and the Centraalbureau voor Schimmelcultures (CBS), Utrecht, the Netherlands. Dried herbarium specimens and dried cultures were deposited at the National Collection of Fungi in South Africa (PREM).

Fungi were studied directly from plant material under a Zeiss Stemi SV6 dissecting microscope and a Zeiss Axioskop 2 Plus light microscope with differential interference contrast (DIC), bright field (BF), or phase contrast ( $\mathrm{PhC})$. Images were captured using an AxioCam ICc 3 camera mounted on the microscopes. Measurements were made of at least 30 structures whenever possible with the aid of Axiovision 4.5 software (AxioVs 40 V 4.6.3.0, Carl Zeiss Ltd., München, Germany). For spore dimensions, average \pm standard deviation was determined and measurements are presented with the extremes given in parentheses. A small piece of tissue containing conidiomata was prepared in Jung tissue freezing medium ${ }^{\mathrm{TM}}$ for cross section and cut in $10-12 \mu \mathrm{m}$ thickness using a Leica CM1100 cryotome.

Culture characteristics were determined for each species in triplicate on 2\% MEA plates. Cultures were incubated for 8-14 d at $25 \mathrm{C}$ in the dark. Colour assignments were made using Rayner (1970).

Fungal colonies were established on MEA plates for extraction of total genomic DNA. Hyphae were harvested and freeze-dried. DNA extractions were done according to Möller et al. (1992). A region spanning the 3' end of the small subunit (SSU), internal transcribed spacers (ITS1, ITS2), the 5.8S gene and part of the large subunit (LSU) of the ribosomal operon were amplified with PCR using the primer set V9G and LR5 (de Hoog \& Gerrits van den Ende 1998, Vilgalys \& Hester 1990). PCR conditions and protocols were the same as those of Gryzenhout et al. (2004) except that 1U Taq DNA polymerase (FABI, University of Pretoria, South Africa) was used. The PCR amplicons were purified using Sephadex columns (Multiscreen HV, Millipore, Bedford, USA). They were sequenced using the same primers used for PCR, and internal primers ITS4 (White et al. 1990) and LR0R (Rehner \& Samuels 1994) on an ABI $3100^{\mathrm{TM}}$ automated DNA sequencer and ABI PRISM ${ }^{\mathrm{TM}}$ Big Dye terminator. A sequencing reaction kit was used according to manufacturer's instructions (Perkin-Elmer, Applied BioSystems, Foster City, USA).

Contigs were created from the sequence data and aligned in CLCBio Main Workbench ver 5.5 (CLCBio, Aarhus, Denmark). Sequence data were deposited in GenBank and accession numbers for each species are given with the respective descriptions. Approximate phylogenetic placements were determined with the BLAST search option of the National Center for Biotechnology Information (NCBI) and the suggested identities are discussed in the descriptive notes below each of the treated species. 


\section{Results and discussion}

Bartalinia pondoensis Marinc., Gryzenh. \& M.J. Wingf., sp. nov.

FIGs. 2-5

MycoBank 515553

Conidiomata pycnidioidea. Conidiophorae ad cellulas conidiogenas reductae. Cellulae conidiogenae holoblasticae, discretae. Conidia versicoloria, cylindrica vel subcylindrica, ter septata, in septo non constricta (19-)21-24(-25.5) $\times 3-4 \mu \mathrm{m}$, cellula basali obconica, hyalina vel subcolorata cellulis, medianis 2 , cylindricis, subcoloratis, cellula secunda e basi (8-)9-10(-11) $\mu \mathrm{m}$ longa, tertia (6-)7-8(-8.5) $\mu \mathrm{m}$ longa, cellula apicali conica, hyalina. Appendiculum apicale 3-ramosum, (10.5-)12-16(-19) $\mu \mathrm{m}$ longa, appendiculum basale unicum, excentricum, (3-)4-6(-6.5) $\mu \mathrm{m}$ longa.

TyPe-Collected 8 May 2008 in Mr. T. Abbott's garden ( $31^{\circ} 02^{\prime} 948^{\prime \prime}$ S, 30 $10^{\prime} 351^{\prime \prime}$ E), Umtamvuna Nature Reserve, Port Edward, KwaZulu Natal, South Africa; in living leaves of Maytenus abbottii (Celastraceae) kept in moisture chamber; S.L. 1423(1), PREM 60359, holotype, ex-type cultures CBS $125525=$ CMW 31067.

EтумоLоgy: named after the visited Pondoland of the Maputaland-Pondoland-Albany biodiversity hotspot

EXPANDED DESCRIPTION - LEAF SPOTS not present, internal, asymptomatic infection. Conidiomata immersed, sub-epidermis, stromatic, pycnidioid, sub-globose or ellipsoidal, 194-226 × 199-266 $\mu \mathrm{m}$, ostiolate, unilocular, often convoluted. Conidiomatal wall 23.0-35.5 $\mu \mathrm{m}$ thick, composed of 3-6 layers of thick-walled, brown cells becoming compressed towards the outside, the outermost layer occasionally intermingled with host cells, inner 1-2 layers composed of thin-walled, sub-hyaline to hyaline cells, 4.0-8.5 $\mu \mathrm{m}$ thick. Conidiophores arising from the lower half of the conidioma, reduced to conidiogenous cells. Conidiogenous CELLS holoblastic, discrete, ampulliform to lageniform or cylindrical, hyaline, (3.5-)4-7(-7.5) $\mu \mathrm{m}$ long. ConIDIA versicolored, cylindrical or sub-cylindrical, straight or slightly curved, 3-septate, with no constrictions at septum, with basal and apical appendages, (19-)21-24(-25.5) × 3-4 $\mu \mathrm{m}$ (av. $22.3 \times 3.5 \mu \mathrm{m})$, length/width ratio 6.4:1; basal cell obconic with a truncate base, hyaline or slightly pigmented, $(2-) 3(-4) \mu \mathrm{m}$

Figs. 2-16. Microscopic images of fungi. Figs. 2-5. Bartalinia pondoensis (holotype, PREM 60359). 2. Vertical section of conidioma. 3. Young conidia attached to conidiogenous cells. 4. Conidium with an apical appendage with 3 branches and an excentric basal appendage. 5. Versicolored conidium (BF). Scale bars: Fig. $2=100 \mu \mathrm{m} ; 3-5=10 \mu \mathrm{m}$. Figs. $6-10$. Crucellisporium umtamvunae (holotype, PREM 60360). 6. Vertical section of conidioma. 7, 9. Conidiogenous cells and developing conidia. 8. Sterile hyphae from the margin of conidioma. 10. Conidium with skewed, attenuated base (arrow). Scale bars: Fig. $6=50 \mu \mathrm{m} ; 7-9=20 \mu \mathrm{m} ; 10=10 \mu \mathrm{m}$. Figs. 11-16. Chaetospermum camelliae 11. Vertical section of conidioma. 12, 13. Young conidia attached to conidiogenous cell in pair $(\mathrm{PhC})$. 14. Conidium filled with minute granules. 15. Conidium with 4 cellular appendages at each end. 16. Conidium showing sub-polar appendages (arrow). Scale bars: Fig. $11=100 \mu \mathrm{m}$; $12-16=10 \mu \mathrm{m}$. 
New coelomycetes from South Africa ... 313

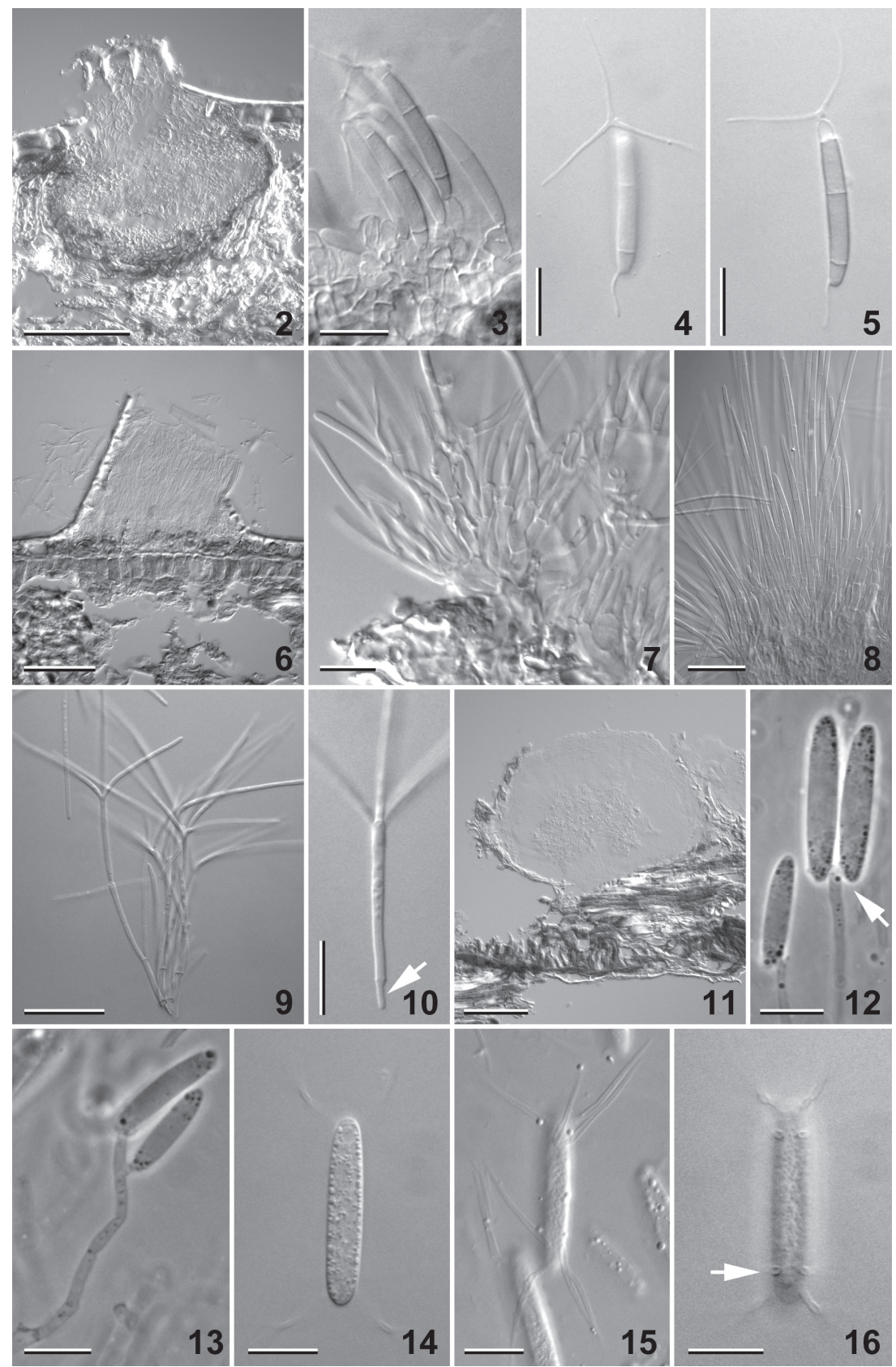


long; 2 median cells, cylindrical, thick-walled, slightly pigmented, (15-)16-18 $(-19) \mu \mathrm{m}$ long (the second cell from the base (8-)9-10(-11) $\mu \mathrm{m}$ long, the third cell from the base (6-)7-8(-8.5) $\mu \mathrm{m}$ long); apical cell conic, hyaline, $2-3 \mu \mathrm{m}$ long, with a short tube $(<1 \mu \mathrm{m}$ long) at the tip where branched appendages are attached; apical appendage with 3 branches, attenuated toward the tip, flexuous, (10.5-)12-16(-19) $\mu \mathrm{m}$ long; basal appendage single, filiform, excentric, (3-) 4-6(-6.5) $\mu \mathrm{m}$ long. Colonies reaching $58.7 \mathrm{~mm}$ in diam after $8 \mathrm{~d}$, sterile, circular with entire margin, flat, with hairy strings of hyphae towards the center, Grey Olivaceous, becoming paler and submerged towards the margin.

Comments - The genus was reviewed by Nag Raj (1993), who studied the then-known 20 species. Six species were accepted in his treatment, four were in question due to a paucity of specimens and sufficient information, three species were transferred to other genera, and two remained unexamined. Since then, four new species have been introduced. The most recent study on the taxonomy of Bartalinia Tassi is by Andrianova \& Minter (2007). These authors provided a key to ten species including the six of those accepted by Nag Raj (1993), three species introduced since the review of Nag Raj (1993), and a new species, which they described as part of the study.

Bartalinia accommodates species having conidia with either three or four septa. Four species are known to have 3-septate conidia similar to $B$. pondoensis, namely B. bischofiae, B. tamarindi, B. bella, and B. bombacicola. Bartalinia bischofiae produces conidioma in pure culture and has conidia in vitro about the same size as $B$. pondoensis with, however, a conidia length/width ratio of $6: 1 ; B$. tamarindi has a $5.7: 1$ conidia length/width ratio; $B$. pondoensis is similar to $B$. bella $(21-26 \times 3.5-5 \mu \mathrm{m})$ in conidial dimensions but is distinguished in having no constriction at the conidial septa and the second cell from the base longer than the third cell; B. bombacicola has shorter conidia $(11-18 \times 3-5 \mu \mathrm{m})$ and longer apical appendage branches (18-32 $\mu \mathrm{m})$ (Nag Raj 1993).

The Blastn search results of the DNA sequence data of B. pondoensis (GenBank GU291796) showed a $99 \%$ similarity to B. laurina (GenBank AF405302) and a 98 or $96 \%$ similarity to two isolates of B. robillardoides (GenBank AF405301, EU552102, respectively). These are the only Bartalinia spp. represented in Genbank with ITS sequences (Jeewon et al. 2002, Marincowitz et al. 2008). Bartalinia laurina has typical 4-septate conidia and occasionally 3-septate ones. Its conidia length/width ratio is 7.4:1 (Nag Raj 1993).

Chaetospermum camelliae Agnihothr., Mycopathologia 16: 115 (1962). FIgs. 11-16 EXPANDED Description - Leaf spots not present, internal, asymptomatic infection. Conidiomata gregarious, pycnidioid, becoming superficial with base immersed in the substratum, gelatinous when moistened, 230-608 $\times$ 
316-750 $\mu \mathrm{m}$, mode opening undetermined. Conidiomatal WALL consisting of a few to many layers of hyaline cells, 18-40 $\mu \mathrm{m}$ thick, textura intricata and gelatinous at the upper $2 / 3$ of the conidioma, pseudoparenchymatous at the base, 14-25 $\mu \mathrm{m}$ thick, consisting of 6-8 hyaline, thick-walled, compressed cells. Conidiophores arising from the lower half of the conidioma, loosely aggregated, sparingly branched and septate at the base. CoNIDIOGENOUs CELLS holoblastic, discrete, cylindrical, 24-47 × 2-2.5 $\mu \mathrm{m}$, bearing an apical cluster of 2 conidia. Conidia hyaline, narrowly ellipsoidal to cylindrical, (25-)26-29 $(-32) \times(4-) 4.5-5 \mu \mathrm{m}($ av. $27.6 \times 4.8 \mu \mathrm{m})$, with sub-polar appendages at both ends, minute granules abundant; appendages mostly 4 at each end, tubular, unbranched, flexuous, 16-22 $\mu \mathrm{m}$ long, 1-2 $\mu \mathrm{m}$ wide at the base becoming attenuated to the tip.

Specimen examined- SOUTH AFRICA. KwaZulu-Natal: Port Edward, Umtamvuna Nature Reserve (Fish Eagle trail)-in living leaves of Syzygium cordatum (Myrtaceae) kept in moisture chamber, 7 May 2008, S.L. 1424(1), PREM 60361.

Hosts - Adiantum tenerum, Archontophoenix alexandrae, Coffea canephora, Cupressus macrocarpa, Ficus pleurocarpa, Hevea sp., Licuala longicalycata, Northia fasciculata, Phragmites australis, Salix sp., Sorbus alnifolia, Syzygium cordatum, Thea sinensis, Trachycarpus fortunei, Typha angustifolia.

Geographical Distribution - AFRICA: Kenya, South Africa; ASIA: China, India, Japan, Republic of Korea, Malaysia, Taiwan, Thailand; AUSTRALASIA: Australia; EUROPE: UK; NORTH AMERICA: Mexico, USA; SOUTH AMERICA: Bermuda, Cuba, French Guiana, Venezuela.

Comments - Nine species and one variety are known for Chaetospermum. Since the most recent treatment by Nag Raj (1993), no new species have been described. He accepted four species, reduced two to synonymy, regarded two as dubious, and did not examine one. Chaetospermum camelliae has been reported on various host plants in many parts of the world. The same species was recorded earlier on the litter of Syzygium cordatum (Crous 1993) but was misidentified as C. chaetosporum (Vadim Mel'nik, pers. comm.).

Crucellisporium umtamvunae Marinc., Gryzenh. \& M.J. Wingf., sp. nov.

MrcoBank 515556

FIGs. 6-10

Conidiomata sporodochiiformia. Hyphae steriles adsunt. Conidiophorae basi ramosae, non vel semel septatae. Cellulae conidiogenae holoblasticae integratae, cylindricae. Conidia hyalina, ex axe principali ramisque facta, axe principali tubulari, (19-)22.5-29(-31) $\times$ (1-)1.5-2 $\mu \mathrm{m}$, non vel ad bis septato, ramis plerumque 3, apicem versus attenuatis (35-) $41-51(-52) \times 1 \mu m$, non vel semel septatis.

TyPE-Collected 7 May 2008, Fish Eagle trail, Umtamvuna Nature Reserve, Port Edward, KwaZulu Natal, South Africa; in living leaves of Nectaropetalum zuluense (Erythroxylaceae) kept in moisture chamber; S.L. 1428(1), PREM 60360, holotype, extype culture CMW 31068. 


\section{6 ... Marincowitz, Gryzenhout \& Wingfield}

EтумоLogy: named after the Umtamvuna Nature Reserve

EXPANDED Description - LeAf spots not present, internal, asymptomatic infection. Conidiomata scattered, acervular, 18-23 $\mu \mathrm{m}$ high, 38-122 $\mu \mathrm{m}$ wide at the base, superficial with a base immersed in the epidermis of substratum, ruptured by lifting up the cuticle. Conidiomatal wall at the base pseudoparenchymatous, textura epidermoidea, composed of 3-5 layers of hyaline, thick-walled cells, at the side textura intricata, $8-16 \mu \mathrm{m}$ wide, composed of 5-7 layers of slightly pigmented, longitudinally elongated cells, with sterile hyphae formed around the margin, individual, hyaline, straight, $2-3 \mu \mathrm{m}$ thick, length varies with regular septation in $8-19 \mu \mathrm{m}$ intervals. ConidiopHORES branched at the base, $0-1$-septate, 10-35 $\mu \mathrm{m}$ long, restricted to the base of the conidioma. Conidiogenous Cells holoblastic, integrated, cylindrical, hyaline, $7.5-20.5 \times 1-2 \mu \mathrm{m}$. Conidia hyaline, consisting of main axis and branches; main axis tubular with a base becoming skewed, attenuated, (19-)22.5-29(-31) $\times(1-) 1.5-2 \mu \mathrm{m}$ (av. $25.5 \times 1.6 \mu \mathrm{m}), 0-2$-septate, becoming slightly thicker at the point of branching; branches (or arms) mostly 3 , attenuated to the tip, (35)41-51(-52) $\times 1 \mu \mathrm{m}$ (av. $45.9 \times 1.2 \mu \mathrm{m}), 0-1$-septate. Colonies reaching 16.3 $\mathrm{mm}$ in diam after $14 \mathrm{~d}$, flat with aerial hyphae bundles, denser near the centre, circular with entire margin, sterile, above hyphae dense, with slight tint of Pale Cinnamon Pink near the center, reverse Pale Cinnamon Pink in the inner half and Cartridge Buff in the outer half.

Comments - Two species, C. selaginellae and C. africanum, are represented in the genus Crucellisporium M.L. Farr. They can be distinguished from C. umtamvunae by conidial characters: Crucellisporium selaginellae has no basal appendage and both the main axis and branches of the conidia are aseptate while C. africanum has shorter conidial branches (14-32 $\mu \mathrm{m}$ long) and basal appendages (0.5-3 $\mu \mathrm{m}$ long) (Nag Raj 1993).

The Blastn search results of the DNA sequence data of C. umtamvunae (GenBank GU291797) showed an 89\% similarity to Hyphodiscus hymeniophilus (Helotiales, Hyaloscyphaceae; Untereiner et al. 2002; GenBank DQ227258), an $89 \%$ similarity to Cryptosporiopsis ericae (Helotiales, mitosporic Dermateaceae; Sigler et al. 2005; GenBank AY540126, AY540126) and an 89\% similarity to Hyalodendriella betulae (Helotiales inc. sed., Crous et al. 2007; GenBank EU040232). A blast search on the AFTOL database (http://aftol.biology. duke.edu/pub/blast/ blastUpload) showed that Lachnum bicolor (177.3005.2; Helotiales, Hyaloscyphaceae), L. virgineum (49.2770.2), Bisporella citrina (1301.5518.2; Helotiales, Helotiaceae), and Neofabraea malicorticis (149.3033.2; Helotiales, Dermateaceae) are closely related (Wang et al. 2006). It is thus clear that $C$. umtamvunae resides in the Helotiales, but its family position remains uncertain. 

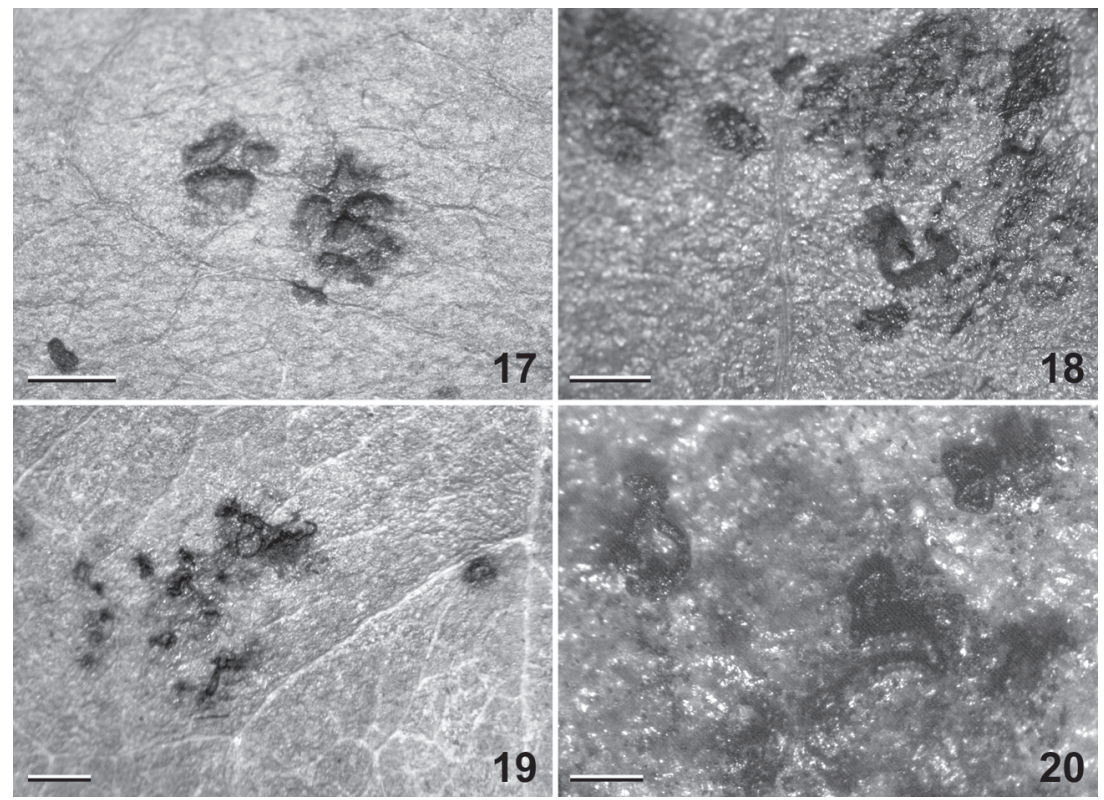

Figs. 17-20. Symptoms of Mycohypallage on living leaves. Figs. 17, 18. M. congesta in purple spots consisting of a few bumps and exudating dark spores in cirrhus. Scale bars: FIG. $17=1 \mathrm{~mm}$; $18=500 \mu \mathrm{m}$. Figs. 19. 20. M. margaretae (holotype, PREM 60364) with exudating dark spores in cirrhi. Scale bars: FIg. $19=1 \mathrm{~mm} ; 20=250 \mu \mathrm{m}$.

Mycohypallage congesta (Berk. \& Broome) B. Sutton, Mycological Papers 88: 5

Figs. 17, 18, 21-25

EXPANDED DESCRIPTION - LEAF SPOTS on the upper side of the leaf, in groups, of dark purple spots, irregularly shaped in 1.0-1.5 $\times 1.0-1.4 \mathrm{~mm}$, each consisting of 3-many bumps of 250-820 $\mu$ m wide, often with exudating dark spores in cirrhi or with scattered dark spores like granules. Conidiomata gregarious, immersed with an ostiole reaching the surface of substratum, sub-epidermis, pycnidioid, at times convoluted, sub-globose or ellipsoidal, $280-320 \times 216-320$ $\mu \mathrm{m}$, ostiole with periphyses brown, septate, 5-6.5 $\mu \mathrm{m}$ thick. Conidiomatal WALL 16-24.5 $\mu \mathrm{m}$ thick, consisting of several layers of highly compressed, hyaline or brown, thick-walled cells, becoming brown around the ostiole. Sterile hyphaE cylindrical, 1-3-septate, brown, arising from all around the inside of conidioma among conidiophores, $20-45 \times 4-5 \mu \mathrm{m}$. Conidiophores reduced to conidiogenous cells. Conidiogenous CELLS holoblastic, discrete, cylindrical, 6-14 × 3-4.5 $\mu \mathrm{m}$. Conidia brown, with wide, paler median band, clavate with an obtuse apex and a truncate base, $(21-) 22-25(-26) \times(9-) 10-11$ 
318 ... Marincowitz, Gryzenhout \& Wingfield

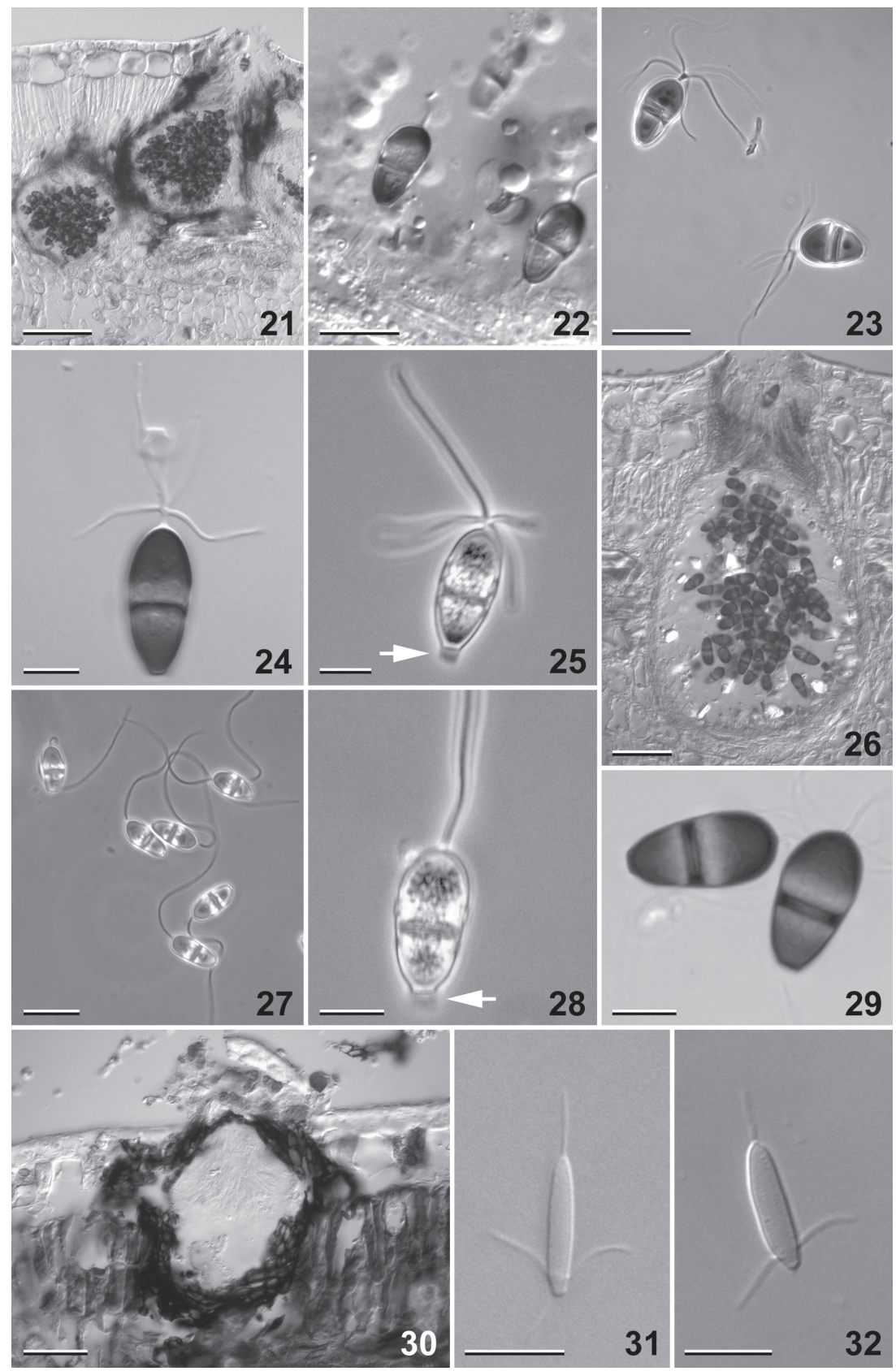


$\mu \mathrm{m}$ (av. $23.4 \times 10.2 \mu \mathrm{m}), 1$-septate, with apical and basal appendages; apical appendage tubular, unbranched for a short length from the base, $1-2(-2.5) \mu \mathrm{m}$ (av. $1.5 \mu \mathrm{m}$ ) and then branching irregularly; branches mostly 4-5, more or less attenuated, flexuous, (17.5-)26-41(-45) $\mu \mathrm{m}$ long (av. $33.5 \mu \mathrm{m})$; basal appendage often present, visible in water, gelatinous, doliiform, 2-4 $\times 3-4.5 \mu \mathrm{m}$.

Specimen eXAmined- SOUTH AFRICA. KwaZulu-Natal: Port Edward, Umtamvuna Nature Reserve (Porcupine trail)-in living leaves of Syzygium cordatum, 8 May 2008, S.L. 1412A, PREM 60362. Red Desert-in living leaves of Syzygium cordatum, 7 May 2008, S.L. 1401C, PREM 60363.

Hosts - Eugenia heyneana, Syzygium cordatum, S. cumini, S. guineense, S. jambolanum, Syzygium sp.

Geographical Distribution - AFriCA: Uganda, South Africa, Zambia; ASIA: India, Sri-Lanka.

Teleomorph - Deshpandiella jambolana (T.S. Ramakr., Sriniv. \& Sundaram) Kamat \& Ullasa, in Ullasa \& Rao, Bull. Torrey Bot. Club 100: 42 (1973).

Comments - Two species were described in Mycohypallage: M. congesta and M. northeae Melnik. However, the second of these was reduced to synonymy with Robillarda sessilis (Sacc.) Sacc. (Nag Raj 1993), so that the genus is currently monotypic. Mycohypallage congesta was reported on living leaves of Syzygium and Eugenia from Africa and Asia (Nag Raj 1993, Farr \& Rossman 2009). Several attempts to grow this fungus in culture failed. Gelatinous basal appendages (Fig. 25) were observed in the specimen recorded here and these have not been seen previously.

Mycohypallage margaretae Marinc., Gryzenh. \& M.J. Wingf., sp. nov.

MrcoBank 515557

Figs. 19, 20, 26-29

Conidia immersa pycnidioidea. Conidiophorae ad cellulas conidiogenas reductae. Cellulae conidiogenae holoblasticae, discretae. Conidia brunnea cum vitta lata pallidiore, clavata apice obtuso basi truncato, (21-)22-25(-26) $\times$ 9-11(-12) $\mu \mathrm{m}$, semel septata, cum appendiculo apicali et appendiculis basalibus; appendiculum apicale tubulare, non ramosum; appendiculum basale saepe adest, in aquo manifestum, gelatinosum doliiforme.

FIGs. 21-32. Microscopic images of fungi. Figs. 21-25. Mycohypallage congesta. 21. Vertical section of conidioma. 22. Young conidia attached to conidiogenous cells. 23. Conidia with an apical appendage of 4-5 branches (PhC). 24. Conidium body with a wide, paler median band. 25. Conidium with a gelatinous basal appendage (PhC, arrow). Scale bars: FIg. $21=100 \mu \mathrm{m}$; $22,23,=20 \mu \mathrm{m} ; 24,25,=10 \mu \mathrm{m}$. FIGs. 26-29. M. margaretae (holotype, PREM 60364). 26. Vertical section of conidioma. 27. Conidia with an unbranched appendage (PhC). 28. Conidium with a gelatinous basal appendage (PhC, arrow). 29. Conidium body with a wide, paler median band (BF). Scale bars: FIg. $26=50 \mu \mathrm{m} ; 27=20 \mu \mathrm{m} ; 28,29=10 \mu \mathrm{m}$. FIGs. 30-32. Mycotribulus mirabilis. 30. Vertical section of conidioma. 31, 32. Conidium with appendages at both ends. Scale bars: FIG. $30=50 \mu \mathrm{m} ; 31,32=10 \mu \mathrm{m}$. 
Type-Porcupine trail, Umtamvuna Nature Reserve, Port Edward, KwaZulu-Natal, South Africa; in living leaves of Syzygium cordatum, 8 May 2008; S.L. 1406A, PREM 60364, holotype.

ЕтумоLоGy: named for Mrs. Margaret (Maggi) Abbott acknowledging her contribution to the knowledge of the flora of Pondoland

Expanded Description - Leaf spots on the upper side of the leaf, discoloured lesions, roughly ellipsoidal, $2.5-5.0 \times 2.0-4.0 \mathrm{~mm}$, consisting of scattered dark bumps, often with exuded dark spores in cirrhi or with scattered dark spores like granules. ConidiomatA immersed with an ostiole reaching the surface of substratum, sub-epidermis, gregarious, pycnidioid, unilocular, often convoluted, sub-globose to ellipsoidal, 275-365.5 × 162-193 $\mu$ m, ostiole with periphyses sub-hyaline to brown, septate, $3-5 \mu \mathrm{m}$ thick. Conidiomatal WALL 10-21 $\mu \mathrm{m}$ thick, consisting of several layers of highly compressed, sub-hyaline to pale brown, thick-walled cells, brown around the ostiole. Conidiophores not observed, probably simple or reduced to conidiogenous cells, arising from all around the conidioma. Conidiogenous CELls holoblastic, discrete, cylindrical. Conidia brown, with a wide, paler median band, clavate with an obtuse apex and a truncate base, $(21-) 22-25(-26) \times 9-11(-12) \mu \mathrm{m}($ av. $23.4 \times 10.4 \mu \mathrm{m})$, 1 -septate, with apical appendage and basal appendages; apical appendage tubular, unbranched, more or less attenuated, flexuous, (55.5-)77.5-93(-95) $\mu \mathrm{m}$ (av. $85.3 \mu \mathrm{m}$ ); basal appendage often present, visible in water, gelatinous, doliiform, $1-1.5 \times 2-3 \mu \mathrm{m}$.

\begin{abstract}
Additional specimens examined - SOUTH AFRICA. KwaZulu-Natal: Port Edward Umtamvuna Nature Reserve (Mr. T. Abbott's garden, 31 $01^{\circ} 948^{\prime \prime} \mathrm{S}, 30^{\circ}$ $10^{\prime} 351^{\prime \prime}$ E)-in living leaves of Syzygium sp. "Van Wyk", 8 May 2008, S.L. 1417C, PREM 60366. Red Desert-in living leaves of Syzygium cordatum, 7 May 2008, S.L. 1400A, PREM 60365.
\end{abstract}

Comments - The second species of Mycohypallage, M. margaretae, can be distinguished from M. congesta by its apical appendage. The former has a single, long appendage whereas $M$. congesta has short, branched appendages. Among the isolates, the appendage of PREM 60365 [(73-)86-100.5(-114) $\mu \mathrm{m}$ long (av. $93.3 \mu \mathrm{m})$ ] was slightly longer than that of the holotype.

Mycotribulus mirabilis Nag Raj \& W.B. Kendr., Canadian Journal of Botany 48(12): 2219 (1970).

FIGs. 30-32

EXPANDEd Description - Leaf Spots not present, internal, asymptomatic infection. Conidiomata immersed, sub-epidermis, pycnidioid, 163-178.5 $\times 152-168 \mu \mathrm{m}$, ostiole absent, dehiscence by irregular rupture on apical wall that reach surface of the substratum. Conidiomatal waLl composed of 3-5 layers of brown, thick-walled, moderately compressed cells, 25.5-29 $\mu \mathrm{m}$ thick. CONIDIOPHORES and CONIDIOGENOUS CELLS not observed, probably due 
to senescent specimen. Conidia hyaline, fusiform with an acute apex and a tapered and truncated base, (13-)14-17(-18) × 3-4 $\mu \mathrm{m}$ (av. $15.5 \times 3.6 \mu \mathrm{m}$ ), aseptate, bearing appendages at both ends; apical appendage, polar, filiform, straight or curved, (6-)7-9(-10) $\mu \mathrm{m}$ long (av. $7.9 \mu \mathrm{m}$ ); basal appendage, mostly 3 , inserted laterally slightly above the truncate base, unbranched, straight or curved, 8-10(-11) $\mu \mathrm{m}$ (av. $9.0 \mu \mathrm{m})$.

Specimen EXAmined- SOUTH AFRICA. KwaZulu-Natal: Port Edward,

Umtamvuna Nature Reserve (Porcupine trail)-in living leaves of Apodytes abbottii (Icacinaceae), 8 May 2008, S.L. 1407D, PREM 60367.

Hosts - Apodytes abbottii, Eucalyptus camaldulensis, E. grandis, E. robusta, E. saligna, E. tereticornis, Eucalyptus sp., Mangifera indica, Syzygium cordatum.

Geographical Distribution - AFRICA: South Africa; ASIA: India, Thailand; NORTH AMERICA: West Indies; PACIFIC: Hawaii; SOUTH AMERICA: Brazil, Cuba.

Comments - This monotypic genus was previously reported on Syzygium cordatum in South Africa (Crous 1993).

\section{Acknowledgments}

Mr. T. Abbott is thanked for his assistance in identifying plants considered in this study. Dr. H. Glen kindly provided Latin translations and Mr. J. Nagel provided DNA sequence data for B. pondoensis and C. umtamvunae. We are grateful to the Rufford Small Grant organization, the NRF/DST Center of Excellence in Tree Health Biotechnology at FABI, University of Pretoria, South Africa for financial support, and the Ezemvelo KwaZuluNatal Wildlife for permission to work in the protected area. We also thank Drs. V. Mel'nik and T. V. Andrianova for their valuable contribution as reviewers.

\section{Literature cited}

Abbott A, Van Wyk AE. 2000. Checklist of the macrofungi, lichens, bryophytes and vascular plants of the Umtamvuna Nature Reserve, South Africa. Lammergeyer 46: 1-69.

Andrianova TV, Minter DW. 2007. New species of Bartalinia and Septoriella from the Altai Mountains (Russia). Mycotaxon 101: 297-313.

Crous PW. 1993. New and interesting records of South African fungi. XIII. Foliicolous microfungi. South African Journal of Botany 59: 602-610.

Crous P.W., Braun U, Schubert K, Groenewald JZ. 2007. Delimiting Cladosporium from morphologically similar genera. Studies in Mycology 58: 33-56.

Farr DF, Rossman AY. 2009. Fungal Databases, Systematic Mycology and Microbiology Laboratory, ARS, USDA. Retrieved April 17, 2009, http://nt.ars-grin.gov/ fungaldatabases/

Gryzenhout M, Myburg H, Van der Merwe NA, Wingfield BD, Wingfield MJ. 2004. Chrysoporthe, a new genus to accommodate Cryphonectria cubensis. Studies in Mycology 50: 119-142.

Hoog GS de, Gerrits van den Ende AHG. 1998. Molecular diagnostics of clinical strains of filamentous Basidiomycetes. Mycoses 41: 183-189.

Jeewon R, Liew ECY, Hyde KD. 2002. Phylogenetic relationships of Pestalotiopsis and allied genera inferred from ribosomal DNA sequences and morphological characters. Molecular Phylogenetics and Evolution 25: 378-392. 
Marincowitz S, Crous PW, Groenewald JZ, Wingfield MJ. 2008. Microfungi occurring on Proteaceae in the fynbos. CBS Biodiversity series 7: 1-166.

Möller EM, Bahnweg G, Sandermann H, Geiger HH. 1992. A simple and efficient protocol for isolation of high molecular weight DNA from filamentous fungi, fruit bodies, and infected plant tissues. Nucleic Acids Research 20: 6115-6116.

Nag Raj TR. 1993. Coelomycetous anamorphs with appendage-bearing conidia. Mycologue Publications: Waterloo, Canada. $1101 \mathrm{pp}$.

Nag Raj TR, Kendrick B. 1978. Genera coelomycetarum. XV. Belaina, Belainopsis and Crucellisporium. Canadian Journal of Botany 56(6): 708-714.

Rayner RW. 1970. A mycological colour chart. Commonwealth Mycological Institute and British Mycological Society: Kew, Surrey, UK. 34 pp.

Rehner SA, Samuels GJ. 1994. Taxonomy and phylogeny of Gliocladium analysed from nuclear large subunit ribosomal DNA sequences. Mycological Research 98: 625-634.

Sigler L, Allan T, Lim SR, Berch S, Berbee M. 2005. Two new Cryptosporiopsis species from roots of ericaceous hosts in western North America. Studies in Mycology 53: 53-62.

Silander JA Jr. 2001. Temperate rainforests. In: Encyclopedia of Biodiversity, Vol. 5, Academic Press, San Diego, USA. 607-626 p.

Steenkamp Y, Van Wyk AE, Victor JE, Hoare DB, Dold AP, Cowling RM, Smith GF. 2004. Maputaland-Pondoland-Albany. In: Mittermeier RA, Hoffmann M, Pilgrim JD, Brooks TB, Mittermeier GC, Lamoureux JL, Da Fonseca G (eds). Hotspots revisited: Earth's biologically richest and most endangered ecoregions. Cemex, Mexico City, Mexico. 392 pp.

Sutton BC. 1980. The Coelomycetes: Fungi Imperfecti with Pycnidia, Acervuli and Stromata. Commonwealth Mycological Institute: Kew, Surrey, UK. 696 pp.

Untereiner WA, Naveau FA, Bachewich J, Angus A. 2006. Evolutionary relationships of Hyphodiscus hymeniophilus (anamorph Catenulifera rhodogena) inferred from $\beta$-tubulin and nuclear ribosomal DNA sequences. Canadian Journal Botany 84: 243-253.

Vilgalys R, Hester M. 1990. Rapid genetic identification and mapping of enzymatically amplified ribosomal DNA from several Cryptococcus species. Journal of Bacteriology 172: 4238-4246.

Wang Z, Binder M, Schoch CL, Johnston PR, Spatafora JW, Hibbett DS. 2006. Evolution of helotialean fungi (Leotiomycetes, Pezizomycotina): A nuclear rDNA phylogeny. Molecular Phylogenetics \& Evolution 41: 295-312.

White TJ, Bruns T, Lee J, Taylor J. 1990. Amplification and direct sequencing, of fungal ribosomal RNA genes for phylogenetics. In: Innis MA, Gelfand, DH, Sninsky JJ, White TJ (eds), PCR protocols: a guide to methods and applications: 315-322. Academic Press, San Diego, California, USA. 